\title{
Ancient Blacksmiths, the Iron Age, Damascus Steels, and Modern Metallurgy
}

\author{
O.D. Sherby and J. Wadsworth
}

This article was submitted to Thermec 2000, International Conference on Processing and Manufacturing of Advanced Materials, Las Vegas, NV, December 4-8, 2000

\section{September 11, 2000}

U.S. Department of Energy

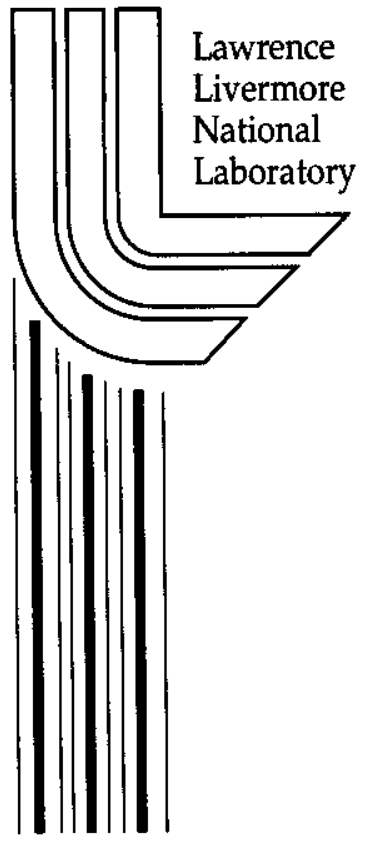




\section{DISCLAIMER}

This document was prepared as an account of work sponsored by an agency of the United States Government. Neither the United States Government nor the University of California nor any of their employees, makes any warranty, express or implied, or assumes any legal liability or responsibility for the accuracy, completeness, or usefulness of any information, apparatus, product, or process disclosed, or represents that its use would not infringe privately owned rights. Reference herein to any specific commercial product, process, or service by trade name, trademark, manufacturer, or otherwise, does not necessarily constitute or imply its endorsement, recommendation, or favoring by the United States Government or the University of California. The views and opinions of authors expressed herein do not necessarily state or reflect those of the United States Government or the University of California, and shall not be used for advertising or product endorsement purposes.

This is a preprint of a paper intended for publication in a journal or proceedings. Since changes may be made before publication, this preprint is made available with the understanding that it will not be cited or reproduced without the permission of the author.

This report has been reproduced directly from the best available copy.

Available to DOE and DOE contractors from the

Office of Scientific and Technical Information

P.O. Box 62, Oak Ridge, TN 37831

Prices available from (423) 576-8401

http://apollo.osti.gov/bridge/

Available to the public from the National Technical Information Service

U.S. Department of Commerce 5285 Port Royal Rd., Springfield, VA 22161

http://www.ntis.gov/

\section{OR}

Lawrence Livermore National Laboratory

Technical Information Department's Digital Library

http://www.llnl.gov/tid/Library.html 


\title{
ANCIENT BLACKSMITHS, THE IRON AGE, DAMASCUS STEELS,
} AND MODERN METALLURGY

\author{
Oleg D. Sherby ${ }^{a}$ and Jeffrey Wadsworth ${ }^{b}$ \\ ${ }^{a}$ Department of Materials Science and Engineering, Stanford University, Stanford, CA 94305, USA \\ ${ }^{b}$ Lawrence Livermore National Laboratory, Livermore, CA 94551, USA
}

\begin{abstract}
The history of iron and Damascus steels is described through the eyes of ancient blacksmiths. For example, evidence is presented that questions why the Iron Age could not have begun at about the same time as the early Bronze Age (i.e. approximately 7000 B.C.). It is also clear that ancient blacksmiths had enough information from their forging work, together with their observation of color changes during heating and their estimate of hardness by scratch tests, to have determined some key parts of the present-day iron-carbon phase diagram. The blacksmiths' greatest artistic accomplishments were the Damascus and Japanese steel swords. The Damascus sword was famous not only for its exceptional cutting edge and toughness, but also for its beautiful surface markings. Damascus steels are ultrahigh carbon steels (UHCSs) that contain from 1.0 to $2.1 \%$ carbon. The modern metallurgical understanding of UHCSs has revealed that remarkable properties can be obtained in these hypereutectoid steels. The results achieved in UHCSs are attributed to the ability to place the carbon, in excess of the eutectoid composition, to do useful work that enhances the high temperature processing of carbon steels and that improves the low and intermediate temperature mechanical properties.
\end{abstract}

Keywords: Ancient blacksmiths, iron age, Damascus steels, superplasticity, pearlite, martensite

\section{Introduction}

Blacksmiths and astronomers were among the elite occupations of ancient times because their work led to an understanding of the nature of earthly and extraterrestrial aspects of life. The blacksmith was the principal contributor to creating the earliest concepts of the behavior and understanding of man-made materials. The astronomer contributed to the mobility of mankind by establishing rules of travel through observation of the stars. Without any doubt, blacksmiths and astronomers were the respected technologists and scientists of their time. Spiritual guidance was provided by astrologers.

\section{A proposed revision of the Metals Ages.}

The Iron Age is commonly thought to have begun around 1000 B.C. The present authors believe, however, that the possibility that the iron age started considerably before the full bronze age must be re-examined; the lack of extensive evidence of their usage is because of the ease of rusting of iron and iron-carbon alloys by oxidation. Furthermore, a rusted object looks ugly and should be buried. Thus, their return to earth's surface as iron oxide destroys the original manufactured iron product. It is important to emphasize, however, that it is relatively easy to make iron since no melting is required. It is much more difficult to manufacture high-tin bronzes since three, separate, melting procedures are required. 
The likelihood of wrought iron being utilized extensively at the start of, and even before, the copper and early Bronze Age is certainly supported by the fact that it is easier to produce. It would also have been motivated by the knowledge that wrought iron is considerably stronger than copper and early (unintentionally alloyed) bronze. This difference in strength (given as hardness) is illustrated in Fig. 1. As can be seen, the hardness of soft copper and early bronze is very low (DPH of 50). If these metals are cold or warm worked, they can be increased in strength by a factor of two. On the other hand, wrought iron, even in its softest condition, has about the same hardness as hardened copper and early bronze. When wrought iron is cold or warm worked its hardness increases by a factor of two, making it considerably superior to copper and early bronze. Damascus steels[1-10], which are ultrahigh carbon steels, are dramatically higher in strength (Fig. 1). Even in its softest condition, Damascus steel is one-and-a-half times stronger than severely worked wrought iron. When Damascus steels are warm worked their hardness is double that of warm worked wrought iron. Furthermore, Damascus steels can be heat treated to obtain very high hardness resulting in steels that are five times stronger than the strongest wrought iron. These steels represent a revolutionary change in the use of metals.

A proposed and provocative sequence of the iron and bronze ages is reconstructed in Fig. 2. The Iron and early Bronze ages are speculated to have begun at a similar time period (i.e. 7000 B.C.). Our selection of 7000 B.C., for the beginning of the Metals Age, is based on the fact that large villages were, by this time, a part of the scene of human activity. Examples are Jericho, and Catal Huyuk and Hallan Cemi in Turkey. The town of Jericho is reported to have had 2500 inhabitants at the time of its prime in 7000 B.C. The story of Catal Huyuk in Turkey is equally impressive with a history dating back to at least 6000 B.C., with a population estimated at over 7,000 people. Evidence of open hearths abounded in these ancient cities. Waldbaum[11] has documented fourteen iron objects at another four sites dating before 3000 B.C. The oldest object is a four-side instrument from a gravesite at Samara in northern Iraq, dated ca. 5000 B.C. The object, which appears to be a tool, was identified as man-made iron. The full Bronze Age and the iron-carbon (Damascus steel) age are depicted, Fig. 2, at about 2500 to 2000 B.C. where alloying was deliberately introduced as a way of increasing the strength of copper and iron. In this period, melting and remelting was extensively used.

\section{Iron making in the prehistory period}

Prehistory is generally considered to be the period before the creation of the Great Pyramids of Egypt, that is, before 3000 B.C. Since much has been recently uncovered in the period from 7000 to 3000 B.C., we propose to classify prehistory as the period before 7000 B.C. Contemporary metallurgists and blacksmiths who have made wrought iron, often consider that such a product could have been made going back to the era of Neanderthal man who dominated the European and African scene from 300,000 to 40,000 years ago. The original wrought iron was probably made in an open hearth where strong winds were available to reduce the starting material, iron oxide ore, into iron according to the reaction:

$$
\text { iron oxide }+ \text { charcoal }+ \text { oxygen }=\text { iron }+ \text { liquid slag }+\mathrm{CO}_{2}
$$

The charcoal is supplied by wood and the temperature does not need to exceed $1000^{\circ} \mathrm{C}$ (much below the melting point of iron). The result is solid iron mixed with liquid slag in a mushy condition, but the end product becomes wrought iron by hammering the mixture to squeeze out much of the liquid slag. There is no direct evidence that Neanderthal man made iron, but it is interesting to speculate on indirect evidence. For example, iron oxide was mined in many places. Iron oxide is known as ochre and 
the most common oxide is hematite $\left(\mathrm{Fe}_{2} \mathrm{O}_{3}\right)$. Millions of pounds of ochre were mined but the large amount of mined ochre is inconsistent with its limited uses. Hearths abound in the Neanderthal age. One Neanderthal area, known to the present authors, is located 150 kilometers northeast of Madrid, Spain at Sierra de Caminos near the town of Ortigosa. This is one of the last remaining Neanderthal sites (about 35,000 BP), and it is believed that extensive mining was done here. Extremely windy conditions prevail at this site creating the possibility of achieving temperatures up to white heat, $1200^{\circ} \mathrm{C}$. This metallurgical view of the Neanderthal man would have it that the race was quite intelligent and progressive. Recent books[12-14] on the Neanderthal man have emphasized the probable gentle nature of these people. They are known to have buried their dead in contrast to the Cro-Magnon man who did not. There is evidence that they created man-made shelters. Their success could have been their demise. A possible scenario is that Cro-Magnon man, who arrived at a later time to Europe and Africa, was the savage and violent human (like Attila the Hun) and progressively eliminated the Neanderthal race and their high technology.

\section{President Herbert Hoover and the Iron Plates of the Great Pyramid}

A fascinating source on the early history of iron making is that from former U. S. President Herbert Hoover. Prior to becoming President, Hoover had an illustrious career in mining and metallurgical engineering. He entered Stanford University in the first freshman class of 1892 and graduated with an $\mathrm{AB}$ degree in mining, metallurgy, and geology. With his wife, Lou Henry, also a Stanford graduate, he translated the 16th century Latin book De Re Metallica by Agricola, and published his famous translation in 1912. In Hoover's book, he annotated Agricola's section on iron with his own views on the history of iron and steel metallurgy. He considered that the Iron Age either fully overlapped the Bronze Age or, even more likely, may have preceded it. Hoover then proceeds to give evidence for the use of ancient iron, "The oldest Egyptian texts extant, dated 3500 B.C., refer to iron, and there is in the British Museum a piece of iron found in the Pyramid of Kephron (3700 B.C.) under conditions indicating its co-incident origin."

The iron plate found in the Pyramid of Kephron (Fig. 3) was taken away and placed in the British Museum in 1837 and remained in the Museum untouched for many decades. The plate was reexamined years later by Sir W.M. Flinters Petrie in 1881. Petrie was acclaimed as 'The Father of Egyptian Archaeology'. He wrote, "It has a cast of a nummulite [fossilized marine protozoa] on the rust of it, proving it to have been buried for ages beside a block of nummulitic limestone, and therefore to be certainly ancient." Since 1881, no serious examination of it was made until over 100 years later. In 1989, two metallurgists from Imperial College, London were able to obtain a piece of the plate for metallurgical examination. Their study revealed that the plate was made up of thin multilayers of wrought iron and low carbon iron. The results indicate that the plate was made by a very laborious blacksmithing process involving bonding of dissimilar plates by heating and hammering them together. A cross-section of the iron piece and its microstructure is shown in Fig. 4. El Gayar and Jones[15], in the final remarks of their published paper stated, "The metallurgical evidence supports the archaeological evidence which suggests that the plate was incorporated within the Pyramid at the time that structure was being built." A carbon dating project done in 1986 indicated that the Great Pyramid was made between 3800 and 2800 B.C.[16]. Carbon dating the iron blade from the Great Pyramid has not been done but would be an important contribution to the history of iron metallurgy, since the age of the plate has indeed been disputed[10]. 


\section{Ancient Blacksmiths and the iron-carbon phase diagram}

The ancient blacksmith had many methods available to create a thorough understanding of the behavior of iron and Damascus steel. The five principal tools were as follows: (1) The first tool is observation of the color of the iron as it is heated for forging or for heat treating. This is the basis of all good blacksmithing. (2) The second tool is determining the strength of iron, characterized by the ease of forging, which is a function of temperature. (3) The third tool is determining the strength and hardness of iron at ambient temperature. This is readily determined by scratching or bending the iron, and is dependent on the temperature of forging and on the cooling rate after forging. (4) The fourth tool, representing a rather scientific method, is the use of lodestone to measure the magnetic qualities of iron (lodestone is a natural magnetic iron oxide mineral). (5) The last tool is having an imagination that iron has two distinct internal structures, a compact one and a less compact one.

Figure 5 illustrates the two principal tools that guided the blacksmith's work. Forging was always in a dark setting. The shop may have been a cave in prehistoric times. First, the blacksmith noted that the wrought iron became weaker (easier to forge) as the temperature increased. In the vicinity of dark orange $\left(900^{\circ} \mathrm{C}\right)$ two dramatic events occurred. For one, the wrought iron suddenly became surprisingly stronger, i.e. more compact-like. For another, the color was noted to change peculiarly in the same temperature range. This is the glitter temperature where a sudden reversal in color change is noted. The temperature seemed to decrease. As the temperature is further increased the resistance to forging decreases again. From all these observations, the blacksmith deduced, correctly, that the iron took on a different condition at the glitter temperature, the dark orange color. This new condition implied a more compact iron was created that was stronger at high temperature. That is, the iron was more dense than its low temperature counterpart.

The blacksmith noted that the properties of wrought iron changed when the iron was combining with carbon. New temperatures were observed for the glitter effect. Nevertheless, a pattern evolved that contains the essence of a primitive iron-carbon phase diagram. This is shown in Fig. 6 where the glitter temperatures are shown, given by a color description, as a function of the amount of charcoal (carbon). The three diamond marks indicate the maximum glitter observed at different temperatures and compositions. The diamond glitter at dark orange is that for wrought iron corroborating the description given earlier in Fig. 5. The second diamond glitter is observed at the medium cherry color with the maximum glitter occurring at a high amount of carbon (about one weight percent of carbon). The third diamond glitter is observed at a very high temperature, close to the maximum achievable in ancient times. The ancient blacksmiths must have wondered how to join the various glitter points to make up some boundaries. Their first guess would be to join the glitter points as shown in Fig. 6 . In addition, the horizontal lines are added as a recognition of the continuation of the glitter effect. The question marks shown in the figure, represent regions which were unclear to the blacksmith. All in all, the diagram shown in Fig. 6, would have represented an admirable attempt by the ancient blacksmiths in the time frame of 2000 B.C. The Damascus Steels of ancient times are located just to the right of the second glitter point in the composition range of about $1 \%$ to $2 \%$ carbon. These steels are designated as ultrahigh carbon steels. The most famous swords in the world are Damascus steel swords and Japanese swords. These swords are famous for their sharp cutting edge, for their artistic beauty, and for the complex blacksmithing required in making them. Both swords usually have ultrahigh carbon steel as the cutting edge of the swords. 


\section{Damascus Steels and Modern Metallurgy}

An example of Damascus steel swords (Persian scimitars) is shown in Fig. 7. They are typically quite curved, more so than the Japanese swords. A photomacrograph is shown between the swords depicting the remarkable surface patterns that have been developed. The pattern is a swirly distribution of proeutectoid carbides (the white areas) adjacent to eutectoid carbides and ferrite. The pattern is achieved by a complex forging procedure. The vertical arrays, known as "Mohammed's ladder", arise from the different directions of upset forging. The beautiful pattern gives a mystic and spiritual feeling. It was believed that they had special healing powers. The method of their manufacture by blacksmiths of ancient times is believed to be a lost and forgotten art. Legends abound that Damascus steels were first developed at the lost continent of Atlantis, and that they were brought to India when Atlantis sank. The Indian steel was widely traded in the form of castings, or cakes, about the size of hockey pucks, known as wootz. The best blades are believed to have been forged by blacksmiths in Persia from Indian wootz, which was also used to make shields, helmets and armor. These steels were known in the middle ages in Russia where they were called "bulat" steels. In Persia, they were known as "pouhad Janherder". These Persian swords were erroneously called Damascus steel swords. This error in the name is because these swords were first observed by European traders in the market-places of Damascus, an important trading center in the $17^{\text {th }}-18^{\text {th }}$ century. The traders apparently did not know that the origin of the swords was in Persia, and that they were made by Persian blacksmiths.

Figure 8 illustrates a drawing of King Puru of India greeting Alexander the Great (about 330 B.C.). This painting is in the guest house of the largest R\&D steel laboratory in the world, the Steel Authority of India, in Ranchi. After King Puru was defeated by Alexander the Great in battle, the King gave, as a token of respect, his sword to Alexander, and behind the King his aide is carrying an additional gift, a gold container within which is a cake of Indian wootz. At the time, this steel was more prized than gold. In a more recent period, the Russian poet, Alexander Pushkin immortalized "bulat" with a similar comparison, when he wrote, in 1830, the following poem: All is mine, said gold; all is mine, said bulat; all I can buy, said gold; all I will take, said bulat. The exact procedures used by the ancient blacksmiths in making the surface markings on genuine Damascus steel swords (it is termed "genuine" because it is made from a single ultrahigh carbon composition casting) have been the source of much speculation. A specific procedure utilizing only a rolling process, known as the "Wadsworth-Sherby" mechanism, has been described by Taleff et al.[9].

In recent years, investigations at Stanford University, at Lawrence Livermore National Laboratory, and at the National Center for Metallurgical Investigations (CENIM) in Madrid, have focused on practical applications of UHCSs. A number of thermal-mechanical processing procedures have been developed to achieve ultrafine structures in these materials and a symposium was held on UHCSs in 1997.[4,5] The major objective was to optimize the use of carbon in excess of the eutectoid composition to create ultrafine spheroidized (spheroidite) structures, ultrafine pearlite structures, and ultrafine martensite structures for achieving desired mechanical properties. These studies led to achieving superplastic behavior in UHCSs at elevated temperature, and to obtaining high strength and high hardness materials at low temperature. Figure 9 illustrates ultrafine spheroidized and pearlitic structures developed in UHCSs by thermal-mechanical working procedures. These are the finest structures ever observed in ingot processed steels. No deleterious carbide network is seen to be present. The possibility of achieving ultrahigh strength wires by cold drawing of a pearlitic structure 
in UHCSs is an objective of contemporary studies. The commercialization of new UHCS materials awaits economical methods of processing through continuous casting and mechanical working.

\section{Conclusions}

Historical studies of ancient metallurgy are an important contribution to understanding the evolution of man and civilization. Knowledge gained from understanding the practices of ancient blacksmiths may well contribute to the development of new processes and new materials. An old Russian proverb states, "The best of the new is often the long forgotten past."

\section{Acknowledgments}

The authors acknowledge close collaboration with many colleagues on the subject of ultrahigh carbon steels. These include Drs. Donald R. Lesuer, Chol K. Syn, Oscar A. Ruano, and Prof. Eric Taleff. The work was performed in part under the auspices of the U.S. Department of Energy by the University of California, Lawrence Livermore National Laboratory under Contract No. W-7405-Eng-48.

\section{References}

[1] Jeffrey Wadsworth and Oleg D. Sherby, Prog. Mat. Sci., 25 (1980) pp. 35-68.

[2] J. Wadsworth and O.D. Sherby, Bulletin of the Metals Museum (of Japan), 4 (1979) 7-23.

[3] O.D. Sherby and J. Wadsworth, Scientific American, 252:2 (1985) 112-120.

[4] J. Wadsworth and O.D. Sherby, in: D.R. Lesuer, C.K. Syn, and O.D. Sherby (Eds.), Thermomechanical Processing and Mechanical Properties of Hypereutectoid Steels and Cast Irons, The Minerals, Metals and Materials Society, Warrendale, PA, 1997, pp. 1-39.

[5] D.R. Lesuer, C.K. Syn, O.D. Sherby, D.K. Kim and J.D. Whittenberger, in: ibid., pp. 175-188.

[6] O.D. Sherby, Jeffrey Wadsworth and Oscar A. Ruano, VI Congreso Nacional de Propriedades Mecanicas de Solidos, Badajoz, Spain, 10-12 June 1998, De Fisica, Facultad de Ciencias, E.T.S. de Ingenierias Industriales, Universidad de Extremadura, Badajoz, Spain, 1998, pp. 35-46.

[7] O.D. Sherby, ISIJ International, 39 (1999) 637-648.

[8] J. Wadsworth, in: E.M. Taleff, C.K. Syn, and D.R. Lesuer (Eds.), Deformation, Processing, and Properties of Structural Materials, The Minerals, Metals and Materials Society, Warrendale, PA, 2000, pp. 3-24.

[9] E.M. Taleff, B.L. Bramfitt, C.K. Syn, D.R. Lesuer, J. Wadsworth, and O.D. Sherby, Processing, Structure, and Properties of a Rolled, Ultra-High-Carbon Steel Plate Exhibiting a Damask Pattern, accepted for publication, Materials Characterization, July 2000.

[10] O.D. Sherby and J. Wadsworth, Ancient Blacksmiths - Their Contribution to the Science and Metallurgy of Iron and Damascus Steel, in preparation, 2000.

[11] J.C. Waldbaum, in: Theodore A. Wertime and James D. Muhly (Eds.), The Coming of the Age of Iron, Yale University Press, New Haven, 1980, pp. 127-150.

[12] Richard Rudgley, The Lost Civilizations of the Stone Age, The Free Press, A Division of Simon and Schuster Inc., 1230 Avenue of the Americas, New York, N.Y. 10020, 1999.

[13] James Shreeve, The Neanderthal Enigma, William Morrow and Company, Inc., 1996.

[14] Ian Tattersall, The Last Neanderthal, Westview Press, 5500 Central Ave, Boulder, CO, 1999.

[15] E.S. El Gayar and M.P. Jones, Jour. Hist. Metall. Soc., 23:2 (1989) 75-83.

[16] Mark Lehner, The Complete Pyramids, Thames and Hudson Ltd., London, 1998. 


\section{Figures}

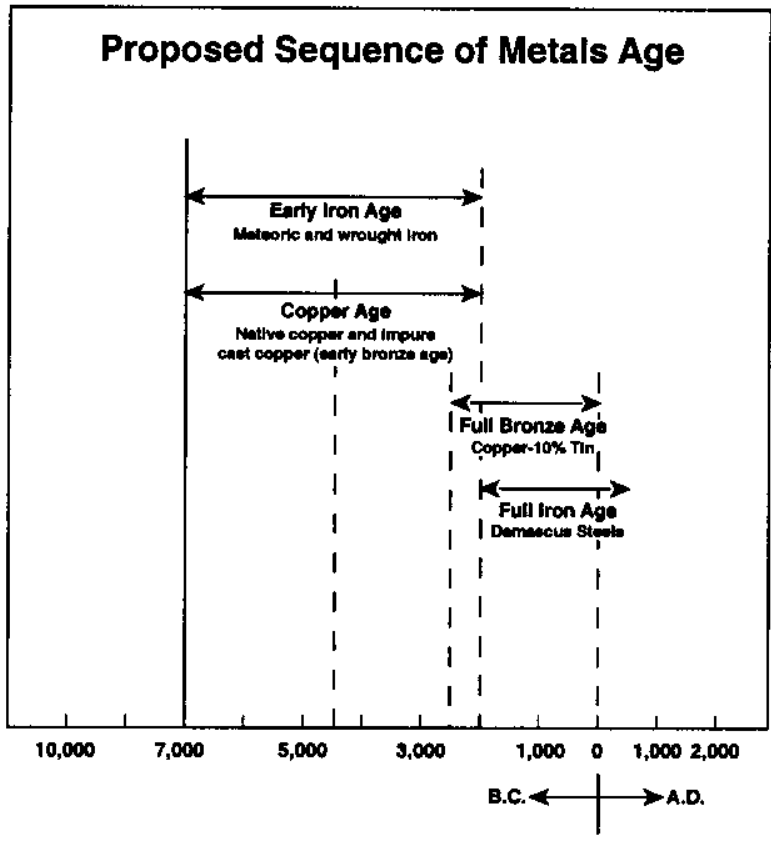

Figure 1. A possible sequence of the Metals Age is proposed.

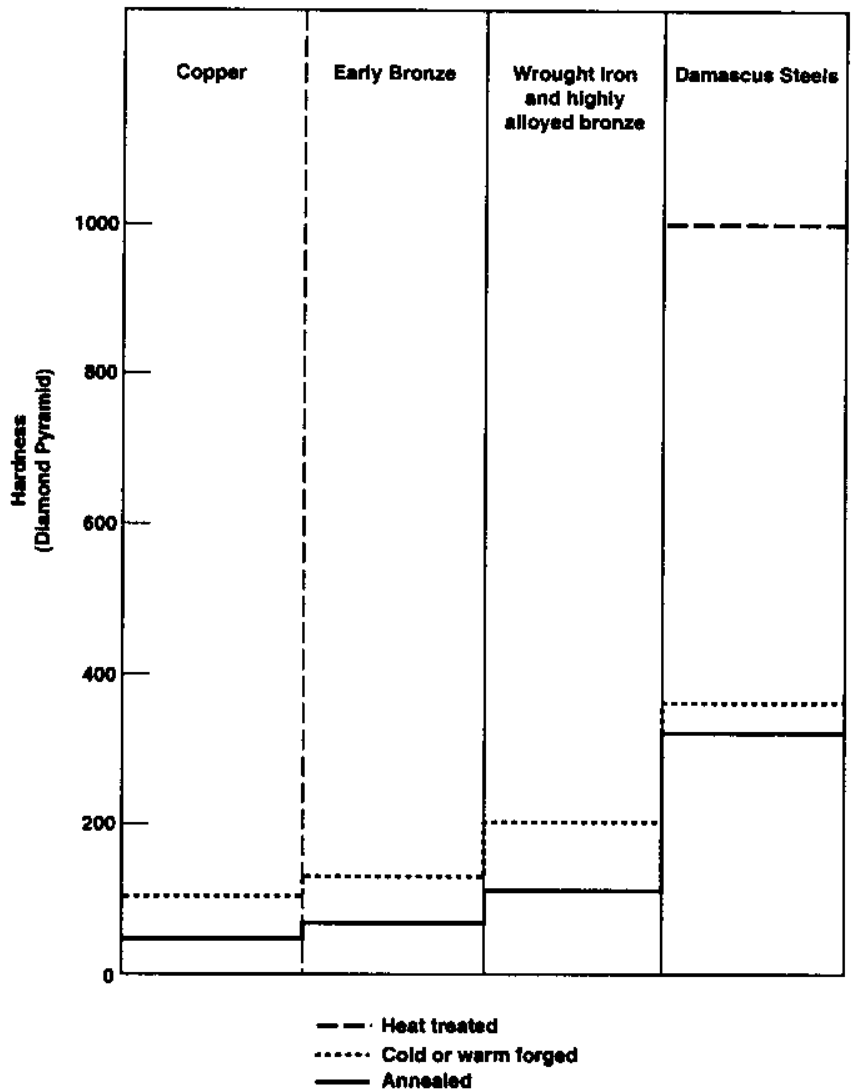

Figure 2. The hardness of copper, low-alloyed (early) bronze, wrought iron and high-alloyed bronze, and Damascus steel. 


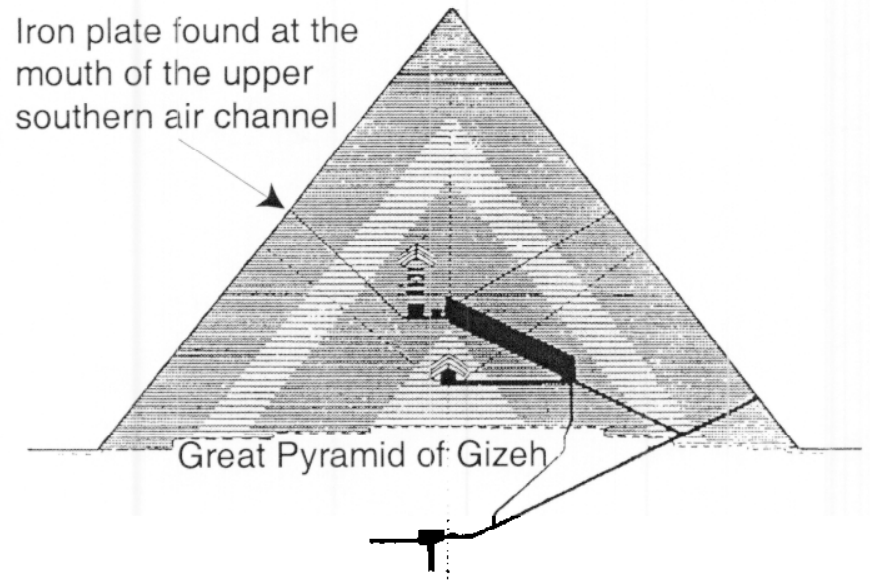

Figure 3. Location of iron plate (after El Gayar[15]).

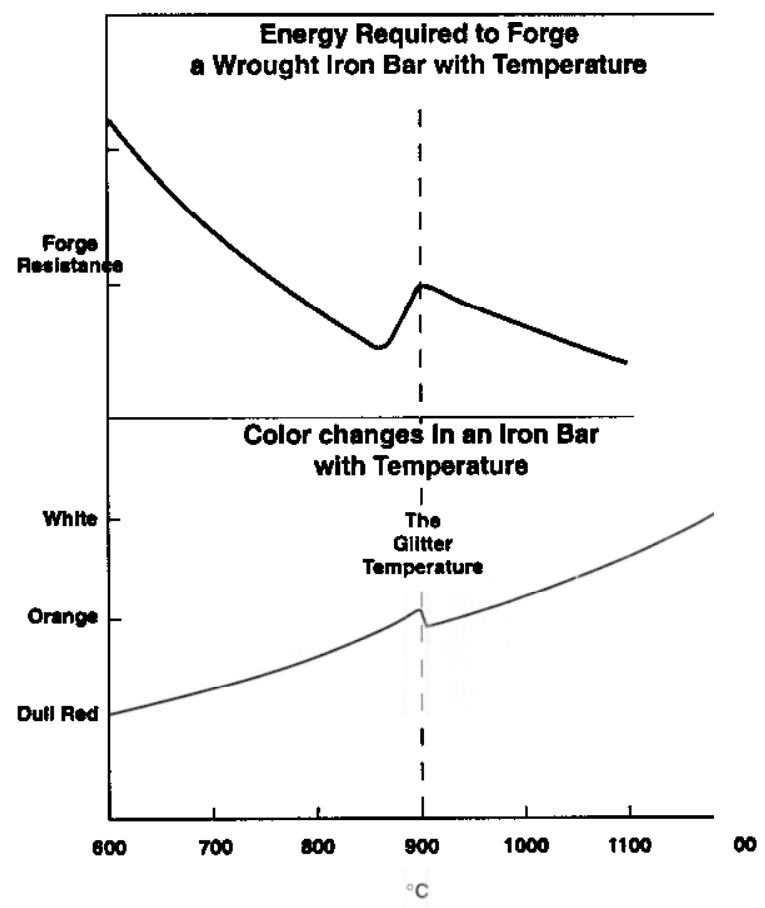

Figure 5. The glitter temperature in wrought iron.

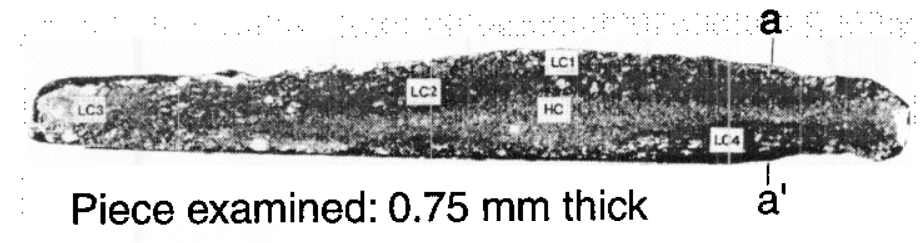

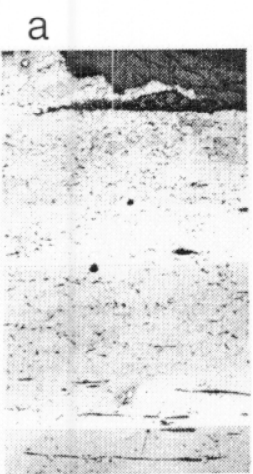

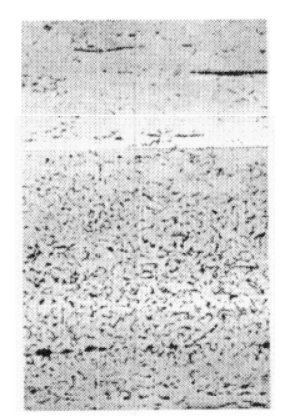

Micrographs of cross section a-a'

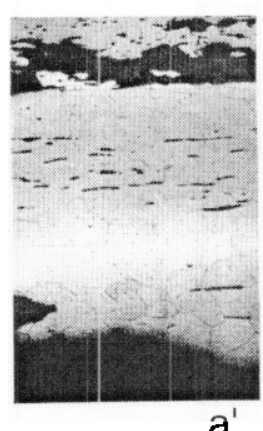

$a^{\prime}$

Figure 4. Microstructure of iron plate (after El Gayar[15]).

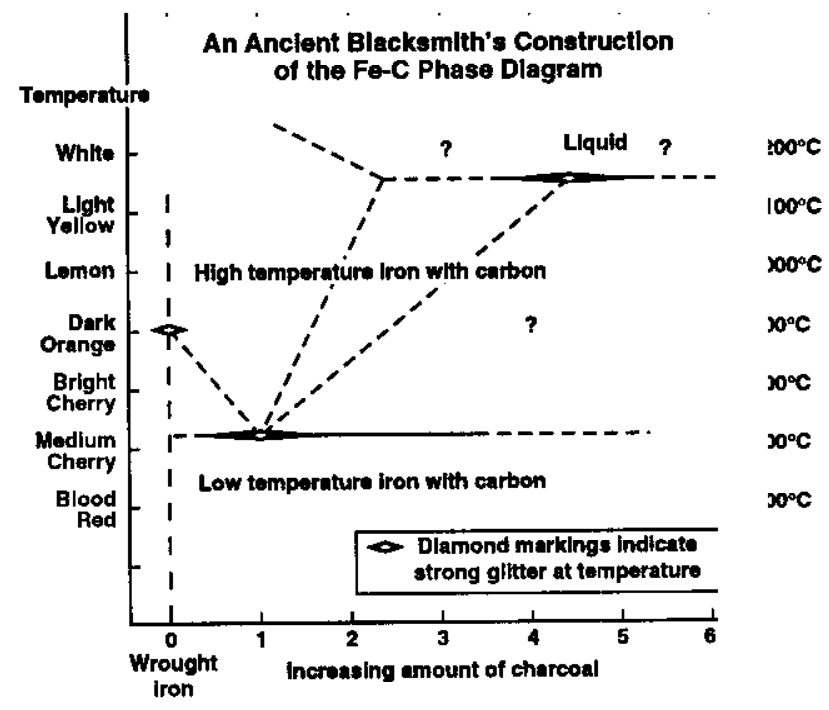

Figure 6. Ancient blacksmith's $\mathrm{Fe}-\mathrm{C}$ phase diagram. 

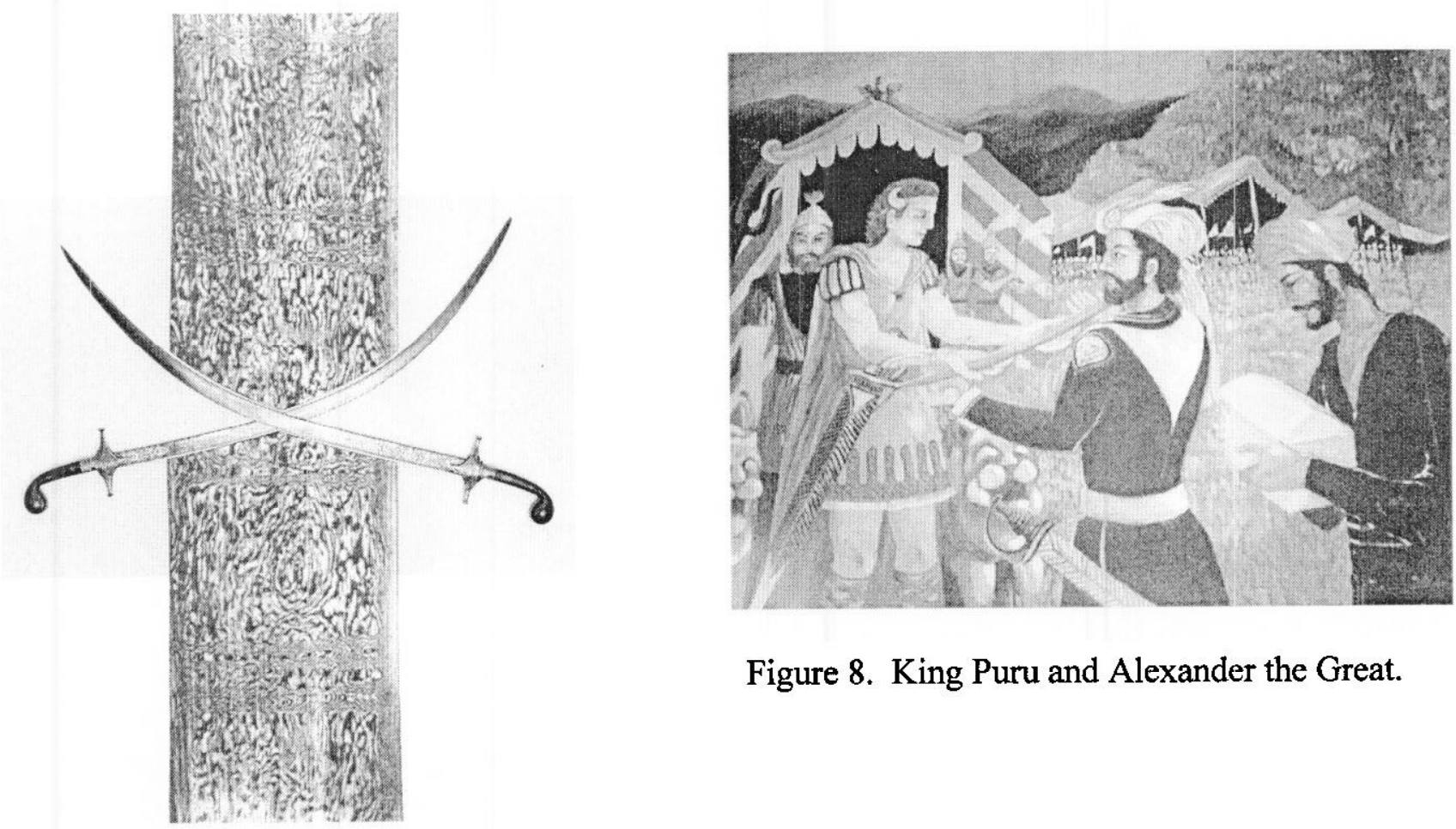

Figure 8. King Puru and Alexander the Great.

Figure 7. Two Damascus swords and surface markings.
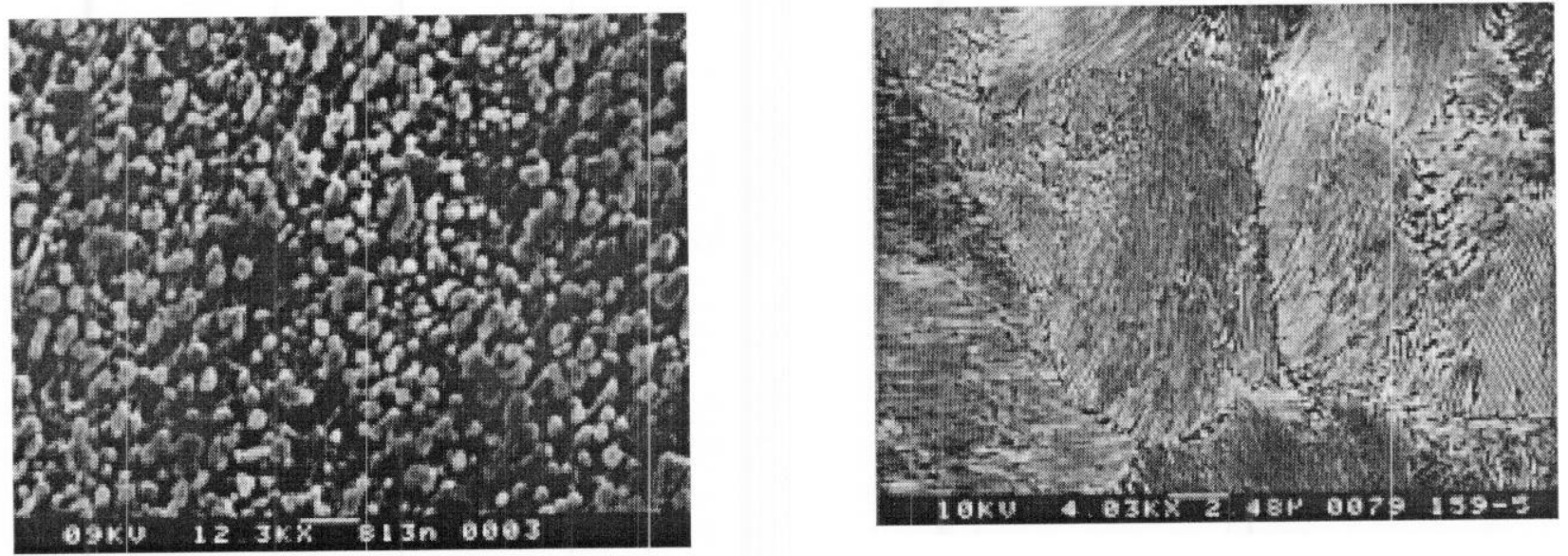

Figure 9. Ultrafine structures in UHCS: spheroidized (left) and lamellar (right). 